Delhi. In Proceedings of the Second FIG Regional Conference, Morocco, 2003.

15. Census of India, Provisional population totals. Office of Registrar General of India, New Delhi, 2011.

16. Mukhopadhyay, A., Mukherjee, S., Garg, R. D. and Ghosh, T., Spatio-temporal analysis of land use-land cover changes in Delhi using remote sensing and GIS techniques. Int. J. Geomat. Geosci., 2013, 4(1), 213-223.

17. Dallimer, M., Rouquette, J. R., Skinner, A. M. J., Armsworth, P. R., Maltby, L. M., Warren, P. H. and Gaston, K. J., Contrasting patterns in species richness of birds, butterflies and plants along riparian corridors in an urban landscape. Divers. Distrib., 2012, 18, 742-753.

18. Soga, M. and Koike, S., Mapping the potential extinction debt of butterflies in a modern city: implications for conservation priorities in urban landscapes. Anim. Conserv., 2013, 16, 1-11.

19. Mallick, J. and Rahman, A., Impact of population density on the surface temperature and micro-climate of Delhi. Curr. Sci., 2012, 102(12), 1708-1713.

20. Pollard, E., A method for assessing changes in the abundance of butterflies. Biol. Conserv., 1977, 12(2), 115-134.

21. Pollard, E., Skelton, M. J. and Thomas, J. A., A method of assessing the abundance of butterflies in Monks Wood National Nature Reserve. Entomol. Gazette, 1975, 26, 79-88.

22. Pollard, E., Van Swaay, C. A. M. and Yates, T. J., Changes in butterfly numbers in Britain and The Netherlands, 1990-91. Ecol. Entomol., 1993, 18(1), 93-94.

23. Kehimkar, I., The Book of Indian Butterflies, Bombay Natural History Society and Oxford University Press, India, 2013, pp. 1-468.

24. Singh, A. P., Butterflies of India, Om Books International, India, 2017, pp. 1-183.

25. Smetacek, P., A Naturalist's Guide to the Butterflies of India, Pakistan, Nepal, Bhutan, Bangladesh and Sri Lanka, John Beaufoy Publshing Limited and Prakash Books, Delhi, 2017, pp. 1-117.

26. Henderson, P. A., Practical Methods in Ecology, Blackwell Publishers, United Kingdom, 2005, pp. 1-148.

27. Vijaylaxmi, C., Rajshekhar, M. and Vijaykumar, K., Freshwater fishes distribution and diversity status of Mullameri River, a minor tributary of Bheema River of Gulbarga District, Karnataka. Int. J. Syst. Biol., 2010, 2, 1-9.

28. Romos, S., Cowen, R. K., Re, P. and Bordalo, A. A., Temporal and Spatial distribution of larval fish assemblages in the Lima estuary (Portugal). Estuarine Coastal Shelf Sci., 2006, 66, 303-314.

29. Harrington, R. and Stork, N. E., Insects in a Changing Environment, Academic Press, United Kingdom, 1995, pp. 431-439.

30. Ockinger, E. and Smith, H. G., Landscape composition and habitat area affect butterfly species richness. Oecologia, 2006, 149, 526534.

31. Ockinger, E., Eriksson, A. K. and Smith, H. G., Effects of grassland management, abandonment and restoration on butterflies and vascular plants. Biol. Conserv., 2006, 133, 291-300.

32. Ockinger, E., Dannestam, A. and Smith, H. G., The importance of fragmentation and habitat quality of urban grasslands for butterfly diversity. Landsc. Urban Plan., 2009, 93, 31-37.

33. Swanson, M. E., Franklin, J. F., Beschta, R. L., Crisafulli, C. M., DellaSala, D. A. and Hutto, R. L., The forgotten stage of forest succession: early-successional ecosystems on forest sites. Front. Ecol. Environ., 2011, 9, 117-125.

34. Chong, K. Y., Teo, S. Y., Kurukulasuriya, B., Chung, Y. F., Rajathurai, S. and Tan, H. T. W., Not all green is as good: different effects of the natural and cultivated components of urban vegetation on bird and butterfly diversity. Biol. Conserv., 2014, 171, 299-309.

35. Van Swaay, C. A. M.., Butterfly densities on line transects in The Netherlands from 1990-2001. Entomol. ber., 2003, 63(4), 8287.
36. Stock, N. E., Watt, A. D. and Larsen, T. B., Butterfly diversity and silvicultural practice in lowland rainforests of Cameroon. Biodivers. Conserv., 2003, 12, 387-410.

37. Tam, K. C. and Bonebrake, T., Butterfly diversity, habitat and vegetation usage in Hong Kong urban parks. Urban Ecosyst., 2016, 19, 721-733.

38. Larsen, T. B., Butterflies of West Africa, Apollo Books, Svendborg, Denmark, 2005, pp. 1-595.

39. Kuussaari, M., Heliola, J., Luoto, M. and Poyry, J., Determinants of local species richness of diurnal Lepidoptera in boreal agricultural landscapes. Agric. Ecosyst. Environ., 2007, 122, 366-376.

40. Lees, A. D., The Physiology of Diapause in Arthropods, Cambridge University Press, England, 2016, pp. 1-14.

41. Dennis, R. L. H., Shreeve, T. G. and Van Dyck, H., Towards a resource-based concept for habitat: a butterfly biology viewpoint. Oikos, 2003, 102, 417-426.

ACKNOWLEDGEMENTS. We thank Guru Gobind Singh Indraprastha University for financial assistance and Indian Agricultural Research Institute, Pusa, New Delhi for giving the permission to conduct the research in their agricultural fields. We also thank Dr M. Shah Hussain (Aravalli Biodiversity Park, New Delhi) for help; and Mr Manish Joshi, Ms Mandeep Kaur and Ms Shubhi Malik (Guru Gobind Singh Indraprastha University, Dwarka, New Delhi) for useful suggestions that helped improve the manuscript.

Received 1 February 2019; revised accepted 30 October 2019

doi: $10.18520 / \mathrm{cs} / \mathrm{v} 118 / \mathrm{i} 5 / 819-827$

\section{Functional response of three species of predatory pirate bugs to different densities of blossom thrips, Frankliniella schultzei Trybom (Thysanoptera: Thripidae)}

\section{Richa Varshney ${ }^{1, *}$, Neeraj Budhlakoti ${ }^{2}$ and Chandish R. Ballal ${ }^{1}$}

${ }^{1}$ ICAR-National Bureau of Agricultural Insect Resources, Post Bag No. 2491, H.A. Farm Post, Bellary Road, Bengaluru 560 024, India

${ }^{2}$ ICAR-Indian Agricultural Statistics Research Institute,

Library Avenue, Pusa, New Delhi, Delhi 110 012, India

The functional response of three anthocorid bugs, namely Blaptostethus pallescens Poppius, Cardiastethus affinis Poppius and Montandoniola indica Yamada (Heteroptera: Anthocoridae) was assessed by feeding them with different densities of thrips larvae of Frankliniella schultzei (Trybom) in the laboratory. Predation rate of all the three species increased with

*For correspondence. (e-mail: richavarshney84@gmail.com) 
increasing prey densities. Both $B$. pallescens and $C$. af finis exhibited type-II response and $M$. indica exhibited type-III response. Among the predators, $M$. indica proved to be effective as it showed highest predation rate, higher $1 / \mathrm{Th}$, higher $\mathrm{a} / \mathrm{Th}$ and lowest handling time followed by $B$. pallescens. It is evident from the present study that $M$. indica and $B$. pallescens could be used in augmentative biological control programmes for thrips.

Keywords: Anthocorid bugs, blossom thrips, functional response, predation rate.

IN an agro-ecosystem, each species interacts with many other species. Prey-predator relationship plays an important role in biological control ${ }^{1}$. Efficiency of the predator depends on how it is able to regulate the density of its prey $^{2}$. Various biological and behavioural studies are required to understand biocontrol potential of a predator. Functional and numerical responses are key components in the selection of highly efficient predators for biological control programmes ${ }^{3}$. The functional response describes the rate at which a predator kills its prey at different prey densities, which shows the efficiency of a predator in regulating prey populations ${ }^{2}$.

Frankliniella schultzei (Trybom) (Thysanoptera: Thripidae), is a polyphagous pest feeding on 83 species of ornamental and vegetable plants covering 55 families worldwide $^{4,5}$. It is also an established vector of several viral diseases, viz. tomato spotted wilt tospovirus (TSWV $)^{6,7}$, tomato chlorotic spot tospovirus (TCSV), groundnut ring spot tospovirus (GRSV) ${ }^{7}$ and tobacco streak ilarvirus (TSV) ${ }^{8}$. In India it has been reported to cause damage to tomato, tobacco, cotton, grain legumes, groundnut and lettuce 9 .

Anthocorids are efficient predators of thrips ${ }^{10-12}$. In addition to thrips, they feed on other insects and by virtue of this habit they are categorized as a generalist predator. For instance, Blaptostethus pallescens Poppius has been observed as a potential predator of maize stem borer Chilo partellus (Swinhoe) ${ }^{13}$ and two-spotted spider mite Tetranychus urticae Koch ${ }^{14}$. Cardiastethus affinis Poppius was recorded as an efficient predator of Opisina arenosella $^{15}$. It was also observed to feed on the eggs and larvae of Corcyra cephalonica (Stainton) and Anadevidia (=Plusia) peponis (Fabricious) in the laboratory ${ }^{15}$. Equally competent are members of the genus Montandoniella ${ }^{11,16}$, of which Montandoniola indica Yamada has been observed to be a prominent predator of a Liothrips karnyi (Bagnall) infesting the foliages of black pepper in Kerala, India ${ }^{17}$. It was also found predating on Gynaikothrips uzeli (Zimmermann) infesting Ficus retusa in Karnataka, India $^{18}$.

In the present study, the three above-mentioned predators have been recorded feeding on $F$. schultzei in the laboratory. Functional response is useful to determine efficacy of predators. Though there are studies on functional response of $B$. pallescens against the eggs of Tuta absoluta Meyrick, there is no study on the type and magnitude of functional response of these anthocorid bugs, viz. B. pallescens, $C$. affinis and $M$. indica against $F$. schultzei. Therefore, the present study was conducted to determine the functional response and predation rate of the above predators to varying densities of $F$. schultzei. This information will be useful to improve our understanding of predator-prey interactions and formulating strategies for the biological control of thrips in general and $F$. schultzei in particular.

Culture of $F$. schultzei was obtained from a capsicum field, Bengaluru, India and identified by an expert at NBAIR, Bengaluru. Thrips adults were exposed to French bean pod for egg-laying. After $24 \mathrm{~h}$, the beans were kept in a separate container for hatching. Once nymphs were hatched, old bean pods were replaced by new ones. The anthocorid predators $B$. pallescens, $C$. affinis and $M$. indica were reared in the laboratory on bean pods (ovipositional substrate) and provided with UVirradiated C. cephalonica eggs as prey ${ }^{18-20}$. All the cultures were maintained at $26^{\circ} \pm 2{ }^{\circ} \mathrm{C}, 65 \% \pm 10 \%$ relative humidity with an approximate photoperiod of $12: 12$ $(\mathrm{L}: \mathrm{D})$. Adequate number of nymphs were raised in the laboratory.

Prior to the functional response study, adults of all the three species of anthocorid bugs were transferred from the stock culture into plastic containers $(200 \mathrm{ml})$ containing tomato leaf disks artificially infested with $F$. schultzei nymphs. One complete generation of all the three predators was maintained on $F$. schultzei to acclimatize them under laboratory conditions to the target prey before initiating the experiment. Young females of each anthocorid species were exposed to different densities of $F$. schultzei. Prior to the experiment, each female was kept starved for $24 \mathrm{~h}$, during which only water was provided. The experiment consisted of a tomato leaf with three leaflets placed ventral side up (avoiding the major veins) on a piece of tissue paper in a small, ventilated round plastic box $(7.5 \mathrm{~cm}$ diameter and $2.5 \mathrm{~cm}$ height). Based on preliminary tests, seven densities $(1,3,6,9,15$, 18 and 30/leaf arena) of $F$. schultzei were presented to each female bug. Nymphs of thrips were transferred on the leaf arena gently using a fine camlin brush. The plastic boxes were held in an incubator $\left(26^{\circ} \pm 2{ }^{\circ} \mathrm{C}\right.$, $65 \% \pm 10 \% \mathrm{RH}, 12 \mathrm{~L}: 12 \mathrm{D}$ photoperiod). The experimental units were examined after $24 \mathrm{~h}$ to record the number of nymphs consumed. For each prey density, five replications were maintained. The prey consumed by the anthocorid females in each replication were not replaced during the experimental period.

The data on consumption rates were analysed by general linear model, to compare the mean number of thrips consumed by each bug for each density. All these analyses were done using SAS 9.3 (ref. 21). 
The shape of the curve was determined by polynomial logistic regression of the proportion of prey consumed as a function of the available prey density. The polynomial function described by Juliano ${ }^{22}$ was used

$$
\frac{N_{a}}{N_{0}}=\frac{\exp \left(P_{0}+P_{1} N+P_{2} N^{2}+P_{3} N^{3}\right)}{\left(1+\exp \left(P_{0}+P_{1} N+P_{2} N^{2}+P_{3} N^{3}\right)\right)},
$$

where $N_{a}$ is the number of prey consumed, $N_{0}$ the initial prey number available and $P_{0}, P_{1}, P_{2}$ and $P_{3}$ are the intercept, linear, quadratic and cubic coefficients respectively, which can be estimated using the maximum likelihood method $^{23}$. If $P_{1}>0$ and $P_{2}<0$, the proportion of prey consumed is positively density-dependent, thus describing a type-III functional response. If $P_{1}<0$, the proportion of prey consumed declines monotonically with the initial number of prey offered, thus describing a type-II functional response ${ }^{22}$. Once the type of functional response was identified, the next step was to estimate searching efficiency $(a)$ and handling time $\left(T_{h}\right)$. In the present analysis, Rogers' type-II random predator equation was adopted instead of Holling's disc equation in order to estimate the functional response parameters, since the latter is based on an assumption of unchanging prey density ${ }^{24}$ and thus not suitable for the present experiment. On the other hand, Roger's type-II equation was preferred for modelling of type-II functional response as it does not assume constant prey density, because prey was depleted during the experiment ${ }^{22,24}$. Rogers' type-II random predator model was fitted using the following equation $^{25,26}$

$$
N_{a}=N_{0}\left\{1-\exp \left[a\left(T_{h} N_{a}-T\right)\right]\right\},
$$

where $N_{a}$ is the number of prey consumed, $N_{0}$ the initial prey density, $a$ the attack rate $\left(\mathrm{h}^{-1}\right), T_{h}$ the handling time (h) and $T$ is the total time $(24 \mathrm{~h})$.

For modelling of type-III functional response with prey depletion, we have used the following equation suggested by Hassell and co-workers ${ }^{27,28}$.

$$
N_{a}=\frac{N_{0}\left\{1-\exp \left[\left(d+d N_{0}\right)\left(T_{h} N_{e}-T\right)\right]\right\}}{\left(1+c N_{0}\right)},
$$

where $a$ increases with prey density and thus cannot be assumed as a constant. In eq. (3), $b, c$ and $d$ are constants from the function that relate $a$ and $N_{0}$ in type-III functional responses

$$
\begin{aligned}
& a=\frac{d+b N_{0}}{1+c N_{0}}, \\
& a=\frac{b N_{0}}{1+c N_{0}} .
\end{aligned}
$$

Here $d$ is not significantly different from 0 , so it was removed.

Predator's attack rate per handling time $\left(a / T_{h}\right)^{29,30}$ and the theoretical maximum number of prey killed in $1 \mathrm{~h}$ could be calculated as $1 / T_{h}$ (ref. 31 ).

Pairwise difference between $B$. pallescens and C. affinis for estimated parameters has also been tested using nonlinear least squares with indicator variables and implicit function (eq. (6)) for data fitted with Rogers ${ }^{1}$ random predator equation ${ }^{22}$

$0=N_{0}-N_{0} \exp \left\{\left[a+D_{a}(j)\right]\left\{\left[T_{h}+D_{T_{h}}(j)\right]\left(N_{a}\right)-T\right\}\right\}$,

where $j$ represents an indicator variable which takes values zero for the first dataset or one for the second dataset. The parameters $D_{a}$ and $D_{T_{h}}$ show differences in searching efficiency and handling time between the two anthocorid species respectively. Specifically, the attack rate for one species is $a$, and that for another species is $a+D_{a}$. If these parameters are significantly different from zero, then the two species differ significantly in the corresponding parameters ${ }^{22,31}$.

Results showed significant difference in predation rate at varying prey densities $(F=198.77, \mathrm{~d} f=6,84$, $P<0.001)$ and for different predator species $(F=35.76$, $\mathrm{d} f=2,84, P<0.001)$. Moreover, the interaction between densities and predator species was also found significant $(F=6.02, \mathrm{~d} f=12,84, P<0.001)$. Results indicated that $M$. indica was able to consume significantly more number of thrips nymphs (22.6) within $24 \mathrm{~h}$ than the other two predator species. Though B. pallescens appeared to consume more number of thrips than $C$. affinis, there was no significant difference between these two predators in terms of predation rate within most of the thrips densities (Table 1).

Based on logistic regression analyses, it was observed that $M$. indica exhibited type-III response because linear parameters were positive whereas the quadratic parameters were negative, and all these parameters were significantly different from zero (Table 2 and Figure 1). This

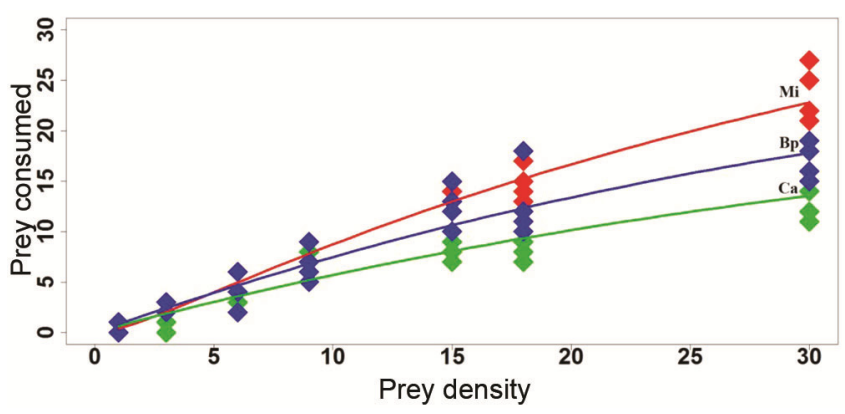

Figure 1. Functional response of anthocorids at different prey densities. Each data point represents the observed number of thrips consumed. Curve was fitted using the Roger's equation. Mi, Montandoniola indica; $\mathrm{Bp}$, Blaptostethus pallescens and $\mathrm{Ca}$, Cardiastethus affinis. 
Table 1. Mean number of thrips larvae (Frankliniella schultzei) consumed by anthocorids

\begin{tabular}{cccc}
\hline & \multicolumn{3}{c}{ Anthocorid predators } \\
\cline { 2 - 4 } Prey density & Blaptostethus pallescens & Cardiastethus affinis & Montandoniola indica \\
\hline 1 & $0.4^{\mathrm{a}} \pm 0.16$ & $0.6^{\mathrm{a}} \pm 0.28$ & $0.4^{\mathrm{a}} \pm 0.24$ \\
3 & $2.6^{\mathrm{a}} \pm 0.24$ & $0.8^{\mathrm{b}} \pm 0.37$ & $2.2^{\mathrm{a}} \pm 0.37$ \\
6 & $4.0^{\mathrm{a}} \pm 0.89$ & $4.2^{\mathrm{a}} \pm 0.8$ & $4.8^{\mathrm{a}} \pm 0.49$ \\
9 & $6.8^{\mathrm{a}} \pm 0.66$ & $6.4^{\mathrm{a}} \pm 0.60$ & $7.6^{\mathrm{a}} \pm 0.68$ \\
15 & $12.4^{\mathrm{a}} \pm 0.81$ & $7.8^{\mathrm{a}} \pm 0.37$ & $13.4^{\mathrm{a}} \pm 0.92$ \\
18 & $12.4^{\mathrm{ab}} \pm 1.43$ & $8.8^{\mathrm{b}} \pm 0.66$ & $15.2^{\mathrm{a}} \pm 0.80$ \\
30 & $16.8^{\mathrm{b}} \pm 0.73$ & $13.6^{\mathrm{b}} \pm 0.92$ & $22.6^{\mathrm{a}} \pm 1.58$ \\
\hline
\end{tabular}

Values bearing lowercase letter compare means among three predators within each egg density in a row. The same lowercase letters are not significantly different (one-way ANOVA, when $P<0.05$ PROC GLM). Each value represents mean $( \pm \mathrm{SE})$ number of thrips larvae consumed by adult females of anthocorid species at $26^{\circ} \pm 2{ }^{\circ} \mathrm{C}$ at various prey densities for $24 \mathrm{~h}$.

Table 2. Logistic model prediction on prey consumption by the anthocorid predators

\begin{tabular}{|c|c|c|c|c|}
\hline \multirow[b]{2}{*}{ Parameters } & & \multicolumn{3}{|c|}{ Anthocorid predators $^{\dagger}$} \\
\hline & & B. pallescens & C. affinis & M. indica \\
\hline Type of response & & II & II & III \\
\hline \multirow[t]{3}{*}{ Constant $\left(P_{0}\right)$} & Intercept & 1.515 & 0.530 & 0.355 \\
\hline & SE & 0.265 & 0.232 & 0.508 \\
\hline & $P$-value & $1.12 \mathrm{e}-08 * * *$ & $0.022 *$ & 0.484 \\
\hline \multirow[t]{3}{*}{ Linear $\left(P_{1}\right)$} & Intercept & -0.039 & -0.024 & 0.183 \\
\hline & $\mathrm{SE}$ & 0.011 & 0.010 & 0.066 \\
\hline & $P$-value & $0.0009 * * *$ & $0.024 *$ & $0.005 * *$ \\
\hline \multirow[t]{3}{*}{ Quadratic $\left(P_{2}\right)$} & Intercept & NA & NA & -0.005 \\
\hline & SE & & & 0.001 \\
\hline & $P$-value & & & $0.002 * *$ \\
\hline
\end{tabular}

*Significant at $P<0.05$. **Significant at $P<0.01$. ***Significant at $P<0.001$. NA: Not applicable. ${ }^{\dagger}$ Maximum likelihood estimates $( \pm \mathrm{SE})$ for parameters of the logistic model fit to proportion of prey consumed versus initial prey density for three anthocorids at $26^{\circ} \pm 2{ }^{\circ} \mathrm{C}$.

indicates that the proportion of $F$. schultzei consumed by $M$. indica is positively density-dependent, which shows a type-III functional response.

The functional response parameters of $M$. indica preying $F$. schultzei over a $24 \mathrm{~h}$ period were estimated using eq. (3). The handling time $\left(T_{h}\right)$ for $M$. indica as estimated by eq. (3) was $0.015 \mathrm{~h}$ (Table 3 ). Attack rate for type-III functional response for this anthocorid bug was also determined using nonlinear least square regression, which indicated that the parameter $d$ was not significantly different from zero, therefore, it was removed from the model and a reduced model was used (eq. (5)). Here, attack rate increased to asymptote. The estimated attack rates of $M$. indica at densities $1,3,6,9,15,18$ and 30 were $0.37,0.69,0.89,0.98,1.06,1.09$ and $1.15 \mathrm{~h}^{-1}$ respectively.

Type-II response was observed for B. pallescens and $C$. affinis (Table 2 and Figure 1). Logistic regression had a significant negative linear parameter $\left(P_{1}<0\right)$, indicating that the proportion of prey consumption decreased as thrips density increased, which further confirms type-II functional response for these predators. The functional response of these two predators over a $24 \mathrm{~h}$ period was estimated by Rogers' random predator equation (eq. (2)). Attack rate of $1.721 \mathrm{~h}^{-1}$ and handling time of $0.027 \mathrm{~h}$ were observed for B. pallescens. Similarly, for C. affinis handling time and attack rate were $0.030 \mathrm{~h}$ and $1.016 \mathrm{~h}^{-1}$ respectively (Table 3 ).

The values of $a / T_{h}$ for $B$. pallescens and $C$. affinis were 63.74 and 33.86 respectively. For $M$. indica, value of $a / T_{h}$ was 24.66, 46, 59.33, 65.33, 70.66, 72.66 and 76.66, at prey densities varied from 1 to 30 . Theoretically, the maximum number of prey killed by $B$. pallescens, $C$. affinis and $M$. indica in $1 \mathrm{~h}$ was $37.03,33.33$ and 66.66 respectively. Pairwise differences between functional response parameters estimated by Rogers' random predatory equation revealed that the value of $D_{a}$ obtained between $B$. pallescens and $C$. affinis was 0.70372 $(0.30136)^{*}(P<0.05)$ and $D_{T_{h}}$ was $-0.00336(0.01428)$.

In the present study, type-III response was observed in $M$. indica, where predation increased after density value 6 , with upper processing limit of 22.6 thrips per $24 \mathrm{~h}$. 


\section{RESEARCH COMMUNICATIONS}

Table 3. Coefficient of attack rate and handling time and other derived parameters for three anthocorid predators

\begin{tabular}{|c|c|c|c|c|c|c|c|c|c|c|}
\hline \multirow[b]{2}{*}{ Predator } & \multicolumn{3}{|c|}{ Attack rate $(a)\left(\mathrm{h}^{-1}\right)$} & \multicolumn{2}{|c|}{$95 \% \mathrm{CI}$} & \multirow{2}{*}{$\begin{array}{c}\text { Handling } \\
\text { time }\left(T_{h}\right)(\mathrm{h})\end{array}$} & \multicolumn{2}{|c|}{$95 \% \mathrm{CI}$} & \multirow[b]{2}{*}{$T / T_{h}$} & \multirow[b]{2}{*}{$1 / T_{h}$} \\
\hline & $a$ & $b$ & $c$ & Lower & Upper & & Lower & Upper & & \\
\hline B. pallescens & 1.721 & - & - & 1.206 & 2.44 & 0.027 & 0.006 & 0.038 & 888.80 & 37.03 \\
\hline C. affinis & 1.016 & - & - & 0.702 & 1.598 & 0.030 & 0.004 & 0.055 & 800 & 33.3 \\
\hline M. indica & -* $^{*}$ & 0.532 & 0.431 & 0.205 & 0.915 & 0.015 & 0.002 & 0.031 & 1600 & 66.6 \\
\hline
\end{tabular}

*In the best-fit type-III model, $a=b N_{0} / 1+c N_{0} ; b$ and $c$ values are given in the table. $N_{0}$ is the initial prey density.

Both $B$. pallescens and $C$. affinis exhibited type-II response, where with increased density the number of thrips consumed increased at a decreasing rate with an upper plateau of 16.8 and 13.6 thrips consumed per $24 \mathrm{~h}$, respectively. Type-II and type-III functional responses were reported earlier for other species of anthocorids. Several studies reported type-II functional response for anthocorids species, like Orius albidipennis Reuter, $O$. majusculus (Reuter), O. laevigatus (Fieber), O. insidiosus (Say), Xylocoris flavipes (Reuter) and Anthocoris minki pistaciae Wagner ${ }^{32-37}$. A type-III functional response was also reported for a few anthocorid species (B. pallescens, Amphiareus constrictus (Stal), O. niger (Wolf.) and $O$. insidiosus) at certain temperatures ${ }^{38-40}$.

Functional response parameters, viz. attack rate and handling time are used to determine the magnitude of functional responses. Handling time is the time spent pursuing, subduing and consuming each prey and that spent while preparing to search for the next prey. In the present study, handling time was less for $M$. indica, followed by $B$. pallescens and C. affinis. However, there was no significant difference between handling time of $B$. pallescens and C. affinis. In the present study, handling time for all predators ranged from 0.015 to $0.030 \mathrm{~h}$. This is commensurate with the findings of Zamani et al. ${ }^{41}$ and Nesrin et $a l^{42}$ who reported values ranging from 0.0122 to $0.0225 \mathrm{~h}$ and 0.005 to $0.012 \mathrm{~h}$ for $O$. albidipennis respectively, when fed on Tetranychus urticae Koch. Nevertheless, higher handling times were reported by other researchers $^{37,40,43}$.

Because $M$. indica showed type-III response, attack rate of this predator is a dynamic parameter which increases with increasing prey density, the attack rate was $1.15 \mathrm{~h}^{-1}$ at the highest density. There was significant difference in the attack rate of B. pallescens and C. affinis. Among all the predators, highest attack rate was observed for $B$. pallescens, which was considerably higher than those for B. pallescens to T. absoluta eggs ${ }^{40} ; O$. albidipennis to Megaleurothrips sjostedti Trybom ${ }^{36}$ and $O$. sauteri (Poppius) to $T$. urticae $e^{43}$. However, it was comparable with the attack rate of 1.613 and $1.267 \mathrm{~h}^{-1}$ for fourth instar and female $O$. albidipennis respectively, when fed on eggs of T. urticae $e^{42}$.

In the present study, predation rate of $M$. indica was 1.34 and 1.66 times more than B. pallescens and C. affi- nis respectively. This may be due to its low handling time, high $a / T_{h}$ and high $1 / T_{h}$ values. Nesrin et al. ${ }^{42}$ and Zamani et $a .^{41}$ reported the highest theoretical predation rate for $O$. albidipennis as 81.96 and 80 respectively, when fed on $T$. urticae.

$M$. indica and $B$. pallescens proved to be efficient predators against common blossom thrips compared to C. affinis. Though the present study was conducted in the laboratory in a small arena, it gives an insight into the behaviour of these anthocorids and their predation rate against common blossom thrips. There are few reports on functional response studies of these three anthocorids. Results of the present study also show that $M$. indica and $B$. pallescens might be considered for augmentative biological control against $F$. schultzei, which is a serious problem in capsicum grown in polyhouses in India. However, ecological characteristics of these predators need to be studied in natural field conditions, where predation would be affected both by biotic and abiotic factors. In field conditions, if these predators are released together there would be many factors like competition and intraguild predation which may affect their role in the suppression of pest population. The predators may occupy different niches, show different prey preferences, host plant preference, etc. Their behaviour, prey preference, and switching to other insect pests must be studied extensively in order to understand the ecology of these predators $^{40}$. Functional response studies can improve our understanding about the behaviour of these predators, but field-based studies are warranted to understand their interaction with different prey and their persistence in the field, which would pave the way to formulate augmentative biocontrol strategies against thrips.

Disclosure statement: No potential conflict of interest has been reported by the authors.

1. Jalali, M. A., Tirry, L. and De Clercq, P., Effect of temperature on the functional response of Adalia bipunctata to Myzus persicae. BioControl, 2010, 55, 261-269.

2. Murdoch, W. W. and Oaten, A., Predation and population stability. Adv. Ecol. Res., 1975, 9, 2-131.

3. Lester, P. J. and Harmsen, S., Functional and numerical responses do not always indicate the most effective predator for biological control: an analysis of two predators in a two-prey system. J. Appl. Ecol., 2002, 39, 455-468. 


\section{RESEARCH COMMUNICATIONS}

4. Palmer, J. M., Identification of the common thrips of tropical Africa (Thysanoptera: Insecta). Trop. Pest Manage., 1990, 36, 27 49.

5. Milne, J. R., Jhumlekhasing, M. and Walter, G. H., Understanding host plant relationships of polyphagous flower thrips, a case study of Frankliniella schultzei (Trybom), In Proceedings of the 1995 Australia and NewZealand Thrips Workshop: Methods, Biology, Ecology and Management (eds Goodwin, S. and Gillespie, P.), NSW Agriculture, Gosford, Australia, 1996, pp. 8-14.

6. Sakimura, K., A comment on the color forms of Frankliniella schultzei (Thysanoptera: Thripidae) in relation to transmission of the tomato-spotted wild virus. Pac. Insects, 1969, 11, 761-762.

7. Wijkamp, I., Almarza, N., Goldback, R. and Peters, D., Distinct levels of specificity in thrips transmission of tospo viruses. Phytopathology, 1995, 85, 1069-1074.

8. Klose, M. J., Sdoodee, R., Teakle, D. S., Milne, J. R., Greber, R. S. and Walter, G. H., Transmission of three strains of Tobacco streak ilar virus by different thrips species using virus-infected pollen. J. Phytopathol., 1996, 144, 281-284.

9. Kakkar, G., Seal, D. R. and Kumar, V., Common blossom thrips scientific name: Frankliniella schultzei Trybom (Insecta: Thysanoptera: Thripidae), 2010; http://entnemdept.ufl.edu/creatures/ veg/thrips/common blossom thrips.htm (accessed on 7 September 2018).

10. Muraleedharan, N. and Ananthakrishnan, T. N., Bioecology of four species of Anthocoridae (Hemiptera: Insecta) predaceous on thrips, with key to genera of anthocorids from India. Occas. Pap., Rec. Zool. Survey India, 1978, 11, 1-32.

11. Ananthakrishnan, T. N., Bionomics of thrips. Annu. Rev. Entomol., 1993, 38, 71-92.

12. Sithanantham, S., Varatharajan, R., Ballal, C. R. and Ganga Visalakshy, P. N. Research status and scope for biological control of sucking pests in India: case study of thrips. J. Biol. Control, 2007, 21, 1-19.

13. Jalali, S. K. and Singh, S. P., Seasonal activity of stem borers and their natural enemies on fodder maize. Entomon, 2002, 27, 137146.

14. Ballal, C. R., Gupta, T., Joshi, S. and Chandrashekhar, K., Evaluation of an anthocorid predator Blaptostethus pallescens against two-spotted spider mite Tetranychusurticae. In Integrated Control in Protected Crops, IOBC/WPRS Bulletin, 2009, vol. 49, pp. 127 132 .

15. Nasser, M. and Abdurahiman, U. C., Reproductive biology and predatory behaviour of the anthocorid bugs (Anthocoridae: Hemiptera) associated with the coconut caterpillar, Opisina arenosella (Walker). Entomon, 1990, 15, 3-4.

16. Muraleedharan, N. and Ananthakrishnan, T. N., Bionomics of Montandoniella moraguesi (Puton) (Heteroptera: Anthocoridae), a predator on gall thrips. Bull. Entomol. Res., 1971, 12, 4-10.

17. Yamada, K., Bindu, K., Nasreem, A. and Nasser, M., A new flower bug of the genus Montandoniola (Hemiptera: Heteroptera: Anthocoridae), a predator of gall-forming thrips on black pepper in southern India. Acta Entomol. Mus. Natl. Pragae, 2011, 51, $1-10$.

18. Ballal, C. R., Gupta, T. and Joshi, S., Morphometry and biology of a new anthocorid Montandoniola indica, a potential predator of Gynaikothrips uzeli. In Integrated Control in Protected Crops, Mediterranean Climate, IOBC-WPRS Bulletin, 2012, vol. 80, pp. 79-84.

19. Ballal, C. R., Singh, S. P., Poorani, J. and Gupta, T., Feasibility of mass multiplication and utilization of Cardiastethus exiguus Poppius, a potential anthocorid predator of Opisina arenosella Walker (Lepidoptera: Oecophoridae). In Biological Control of Lepidopteran Pests (Tandon, P. L., Ballal, C. R. and Jalali, S. K.), 2003, pp. 29-33.

20. Ballal, C. R., Singh, S. P., Poorani, J. and Gupta, T., Biology and rearing requirements of an anthocorid predator, Blaptostethus pal- lescens Poppius (Heteroptera:Anthocoridae). J. Biol. Control., 2003, 17, 29-33.

21. Base SAS ${ }^{2} 9.3$ Procedures Guide. SAS Institute Inc, Cary, North Carolina, USA, 2011.

22. Juliano, S. A., Non-linear curve fitting: predation and functional response curves. In Design and Analysis of Ecological Experiments (eds Scheiner, S. M. and Gurevitch, J.), Chapman and Hall, New York, USA, 2001, 2nd edn, pp. 178-196.

23. Pervez, A. and Omkar, Functional responses of coccinellid predators: an illustration of a logistic approach. J. Insect Sci., 2005, 5, 319-325.

24. Rogers, D., Random search and insect population models. J. Anim. Ecol., 1972, 41, 369-383.

25. Pritchard, D., Frair: Tools for Functional Response Analysis 2017. R package version 0.5.100; https://github.com/dpritchard/frair

26. R Core Team, R: a language and environment for statistical computing. R Foundation for Statistical Computing Vienna, Austria, 2017; https://www.R-project.org/

27. Hassell, M. P., Lawton, J. H. and Beddington, J. R., Sigmoid functional responses by invertebrate predators and parasitoids. J. Anim. Ecol., 1977, 46, 249Đ262.

28. Hassell, M. P., The Dynamics of Arthropod Predator prey Systems, Princeton University Press, Princeton, NJ, USA, 1978.

29. Hassell, M. P., The Spatial and Temporal Dynamics of Host Parasitoid Interactions, Oxford University Press, Oxford, UK, 2000.

30. Varshney, R., Budhlakoti, N. and Ballal, C. R., Functional response of Geocoris ochropterus Fieber (Hemiptera: Geocoridae) to different egg densities of Helicoverpa armigera (Hübner). Phytoparasitica, 2018, 46, 451-458.

31. Behnazar, T. and Madadi, H., Functional response of different stages of Hippodamia variegate (Col.: Coccinellidae) to Diuraphis noxia (Hemiptera: Aphididae) on two wheat cultivars. Biocontrol. Sci. Technol., 2015, 2, 1180-1191.

32. Isenhour, D. J., Layton, R. C. and Wiseman, B. R., Potential of adult Orius insidiosus (Hemiptera: Anthocoridae) as predator of the fall armyworm Spodoptera frugiperda (Lepidoptera: Noctuidae). Entomophoga, 1990, 35, 169-275.

33. Coll, M. and Ridgway, R. L., Functional and numerical responses of Orius insidiosus (Heteroptera: Anthocoridae) to its prey in different vegetable crops. Ann. Entomol. Soc. Am., 1995, 88, 732-738.

34. Montserrat, M., Albajes, R. and Castane, C., Functional response of four heteropteran predators preying on greenhouse whitefly (Homoptera: Aleyrodidae) and western flower thrips (Thysanoptera: Thripidae). Environ. Entomol., 2000, 29, 1075-1082.

35. Donnelly, B. E. and Phillips, T. W., Functional response of Xylocoris flavipes (Hemiptera: Anthocoridae): effects of prey species and habitat. Environ. Entomol., 2001, 30, 617-624.

36. Gitonga, L. M., Lohr, B., Overholt, W. A., Magambo, J. K. and Mueke, J. M., Effect of temperature on the development of Orius albidipennis Reuter, a predator of the African legume flower thrips, Megalurothrips sjostedti trybom. Insect Sci. Appl., 2002, 22, 215-220.

37. Kheradmand, K., Pourali, Z. and Jamshidnia, A., Influence of temperature on the functional response of the predatory bug, Anthocoris minki pistaciae (Hemiptera: Anthocoridae), a predator of Agonoscena pistaciae (Hemiptera: Psyllidae). Zool. Ecol., 2017, 26, 64-68.

38. McCaffrey, J. P. and Horsburgh, R. L., Functional response of Orius insidiosus (Hemiptera: Anthocoridae) to the European red mite Panonychus ulmi (Acari: Tetrnychidae), at different constant temperatures. Environ. Entomol., 1986, 15, 532-535.

39. Jalalizand, A., Modaresi, M., Tabeidian, S. A. and Karimy, A., Functional response of Orius niger niger (Hemiptera: Anthocoridae) to Tetranychus urticae (Acari: Tetranychidae): effect of host plant morphological feature. In International Conference on Food Engineering and Biotechnology: IPCBEE 9, IACSIT Press, Singapore, 2011. 
40. Queiroz, O. S., Ramos, R. S., Gontijo, L. M. and Picanco, M. C., Functional response of three species of predatory pirate bugs attacking eggs of Tuta absoluta (Lepidoptera: Gelechiidae). Environ. Entomol., 2015, 44, 246-251.

41. Zamani, A., Vafaei, S., Vafaei, R., Goldasteh, S. and Kheradmand $\mathrm{K}$, Effect of host plant on the functional response of Orius albidipennis (Hemiptera: Anthocoridae) to Tetranychus urticae (Acari: Tetranychidae). IOBC/WPRS, 2009, Bull 50, 125-129.

42. Nesrin, A., Basha, E., Salman, M. S. and Osman, M. A., Functional response of Orius albidipennis to two spotted spider mite, Tetranychus urticae (Acari: Tetranychidae). J. Entomol., 2012, 9, $248-256$.
43. Xu, X. and Enkegaard, A., Prey preference of Orius sauteri between western flower thrips and spider mites. Entomol. Exp. Appl., 2009, 132, 93-98.

ACKNOWLEDGEMENTS. We thank the Indian Council of Agricultural Research, New Delhi, for providing the necessary facilities, and Mrs Shashikala Kadam and late Mr Raja for maintaining all the anthocorid cultures in the laboratory. We also thank Ms Rachana Remani (ICAR-NBAIR Bengaluru) for the identification of thrips.

Received 25 September 2019; revised accepted 31 October 2019 doi: $10.18520 / \mathrm{cs} / \mathrm{v} 118 / \mathrm{i} 5 / 827-833$

\section{OURRENT SEIENGE \\ Display Advertisement Rates}

\begin{tabular}{|c|c|c|c|c|c|c|c|}
\hline India & \multicolumn{7}{|c|}{ Tariff (Rupees)* } \\
\hline \multirow[b]{2}{*}{ Size } & \multirow{2}{*}{$\begin{array}{l}\text { No. of } \\
\text { insertions }\end{array}$} & \multicolumn{2}{|c|}{ Inside pages } & \multicolumn{2}{|c|}{ Inside cover pages } & \multicolumn{2}{|c|}{ Back cover pages } \\
\hline & & $B \& W$ & Colour & $B \& W$ & Colour & $B \& W$ & Colour \\
\hline \multirow{7}{*}{$\begin{array}{l}\text { Full page } \\
\left(\begin{array}{l}(H=23 \mathrm{~cm} \\
W=17.5 \mathrm{~cm})\end{array}\right.\end{array}$} & 1 & 18,000 & 30,000 & 25,000 & 40,000 & 35,000 & 45,000 \\
\hline & 2 & 33,000 & 55,000 & 47,000 & 76,000 & 65,000 & 86,000 \\
\hline & 4 & 62,000 & $1,05,000$ & 92,000 & $1,46,000$ & $1,25,000$ & $1,65,000$ \\
\hline & 6 & 90,000 & $1,50,000$ & $1,25,000$ & $2,00,000$ & $1,75,000$ & $2,25,000$ \\
\hline & 8 & $1,10,000$ & $1,87,000$ & $1,68,000$ & $2,65,000$ & $2,30,000$ & $3,00,000$ \\
\hline & 10 & $1,35,000$ & $2,25,000$ & $1,98,000$ & $3,15,000$ & $2,70,000$ & $3,60,000$ \\
\hline & 12 & $1,80,000$ & $3,00,000$ & $2,50,000$ & $4,00,000$ & $3,50,000$ & $4,50,000$ \\
\hline \multirow{7}{*}{$\begin{array}{l}\text { Half page } \\
\left(\begin{array}{l}(H=11 \mathrm{~cm} ; \\
W=17.5 \mathrm{~cm})\end{array}\right.\end{array}$} & 1 & 10,000 & 18,000 & \multirow{7}{*}{$\begin{array}{l}\text { Quarter page } \\
\qquad \begin{array}{l}(H=11 \mathrm{~cm} ; \\
W=8 \mathrm{~cm})\end{array}\end{array}$} & \multirow{2}{*}{$\begin{array}{c}\text { No. of } \\
\text { insertions }\end{array}$} & \multicolumn{2}{|c|}{ Inside pages } \\
\hline & 2 & 19,000 & 33,000 & & & B\&W & Colour \\
\hline & 4 & 35,000 & 62,000 & & 1 & 6,000 & 12,000 \\
\hline & 6 & 50,000 & 90,000 & & 6 & 30,000 & 60,000 \\
\hline & 8 & 60,000 & $1,10,000$ & & 12 & 60,000 & $1,20,000$ \\
\hline & 10 & 72,000 & $1,35,000$ & & & & \\
\hline & 12 & $1,00,000$ & $1,80,000$ & & & & \\
\hline $\begin{array}{c}\text { Other } \\
\text { Countries }\end{array}$ & \multicolumn{7}{|c|}{ Tariff (US \$)* } \\
\hline \multirow[b]{2}{*}{ Size } & \multirow{2}{*}{$\begin{array}{c}\text { No. of } \\
\text { insertions }\end{array}$} & \multicolumn{2}{|c|}{ Inside pages } & \multicolumn{2}{|c|}{ Inside cover pages } & \multicolumn{2}{|c|}{ Back cover pages } \\
\hline & & B\&W & Colour & $B \& W$ & Colour & $B \& W$ & Colour \\
\hline \multirow{2}{*}{$\begin{array}{l}\text { Full page } \\
(H=23 \mathrm{~cm} ; \\
W=17.5 \mathrm{~cm})\end{array}$} & 1 & 300 & 650 & 450 & 750 & 600 & 1000 \\
\hline & 6 & 1500 & 3000 & 2250 & 3500 & 3000 & 5000 \\
\hline \multirow{2}{*}{$\begin{array}{l}\text { Half page } \\
(\mathrm{H}=11 \mathrm{~cm} ; \\
\mathrm{W}=17.5 \mathrm{~cm})\end{array}$} & 1 & 200 & 325 & & & & \\
\hline & 6 & 1000 & 2000 & & & & \\
\hline
\end{tabular}

* $25 \%$ rebate for Institutional members

Note: For payments towards the advertisement charges, Cheque (at par/multicity) or Demand Drafts may be drawn in favour of 'Current Science Association, Bengaluru'.

Contact us: Current Science Association, C.V. Raman Avenue, P.B. No. 8001, Bengaluru 560080 or e-mail: csc@ias.ac.in

Last date for receiving advertising material: Ten days before the scheduled date of publication.

[The jurisdiction for all disputes concerning submitted articles, published material, advertisement, subscription and sale will be at courts/tribunals situated in Bengaluru city only.] 